\title{
KONSEP KEBAHAGIAAN DALAM PANDANGAN PSIKOLOGI SUFISTIK
}

\author{
Rofi'udin \\ PNS Kementerian Agama Magetan \\ Alumni Konsentrasi Psikologi Pendidikan Islam \\ Universitas Muhammadiyah Yogyakarta (UMY) \\ e-mail: rofi_udin@yahoo.com
}

\begin{abstract}
This article aims to enalyze the concept of happiness which on the market by psychology of sophistic and any kind of differentiating it from contemporary psychology. The characteristic of concept of happiness in the sufistic psychology is ethic transcendental. The happiness is mean as giving of God and not results of human effort. In spite of that, the human must endeavour in order that God disposed to give the giving of happiness. Its implementation and implication, the happiness in psychology of sophistic is obtained from comprehension that pleasure, wealth, and achievement of life are goal, but only medium to reach spiritual happiness. With method of takhalli, tahalli, tajalli, mujāhadah, riyādah, etc., the sufistic psychology offers real happiness.
\end{abstract}

Abstrak:Artikel ini bertujuan untuk menganalisis konsep kebahagiaan yang ditawarkan oleh psikologi sufistik dan apa saja yang membedakannya dari psikologi kontemporer. Konsep kebahagiaan dalam psikologi sufistik bersifat etis transendental. Kebahagiaan dimaknai sebagai anugerah Allah dan bukan berasal dari hasil usaha manusia. Meski demikian, manusia dituntut berusaha agar Allah berkenan memberi anugerah kebahagiaan itu dengan cara mengikuti tuntunanNya. Dalam implementasi dan implikasinya, kebahagiaan dalam psikologi sufistik didapatkan dari pemahaman bahwa bahwa kesenangan, kekayaan, dan pencapaian hidup lainnya bukanlah tujuan, tetapi sekadar sarana dalam meraih kebahagiaan spiritual. Dengan metode takhallī, taḥalli, tajallī,mujāhadah, riyādah, dan sebagainya, psikologi sufistik menawarkan kebahagiaan yang hakiki dalam ma'rifah dan rida Allah.

TEOLOGIA, VOLUME 24, NOMOR 2, JULI-DESEMBER 2013 
ROFI'UDIN: Konsep Kebahagiaan...

Keywords: kebahagiaan, psikologi kontemporer, psikologi sufistik, kebahagiaan statistik vs sufistik

\section{A. Pendahuluan}

Masalah kebahagiaan dan kesengsaraan adalah masalah kemanusiaan yang paling hakiki. Sebab tujuan hidup manusia tak lain ialah memperoleh kebahagiaan dan menghindari kesengsaraan. Semua ajaran, baik yang bersifat keagamaan maupun yang bersifat keduniaan semata menjanjikan kebahagiaan bagi pengikutnya dan mengancam para penentangnya dengan kesengsaraan. Gambaran tentang wujud kebahagiaan atau kesengsaraan itu sangat beraneka ragam. Namun semua ajaran dan ideologi selalu menegaskan bahwa kebahagiaan yang dijanjikannya atau kesengsaraan yang diancamkannya adalah jenis yang paling sejati dan abadi. ${ }^{1}$

Kebahagiaan dalam pandangan setiap orang identik dengan kemudahan memperoleh fasilitas yang menyenangkan, mendapatkan status sosial tinggi, dan kesejahteraan. Hal ini mengindikasikan bahwa dalam memori publik setiap orang yang bahagia dipastikan orang itu sukses, sejahtera dan mendapatkan status sosial tinggi, meskipun sebenarnya dalam realita tidaklah pasti seperti itu, tergantung dari ukuran kebahagiaan itu sendiri. Di saat tiap orang ingin hidup bahagia, kenyataannya banyak orang justru hidup menderita. Karena itu, hidup bahagia tidak bisa diharapkan datang dengan sendirinya, tetapi harus diusahakan dengan sikap hidup yang relevan dengan tuntunan hidup bahagia.

Meski terlihat sederhana, terma kebahagiaan ternyata dipahami secaraberagam, mulai dari perasaan yang menyenangkan, terhindarnya kesusahan, kepuasan hidup dan kesenangan yang mendalam, hingga kesejahteraan dalam dimensi lahir dan batin. Kebahagiaan juga dibagi dalam tingkatan-tingkatannya, cara meraihnya, serta dimensi eskatologisnya. Namun semua menunjuk pada satu tujuan bersama, cita-cita manusia yang universal, dengan beberapa differensiasinya. 
ROFI'UDIN: Konsep Kebahagiaan...

\section{B. Pandangan Psikologi tentang Kebahagiaan}

\section{Psikoanalisa}

Sigmund Freud mengajukan prinsip kesenangan (pleasure principle) sebagai prinsip dalam meraih kebahagiaan. Dalam teorinya itu, Freud tanpa ragu menyebut bahwa segala yang dirasakan oleh peristiwa mental secara otomatis diatur oleh prinsip kesenangan. Peristiwa-peristiwa mental selalu saja menimbulkan ketegangan yang tidak menyenangkan, tetapi kemudian menuju pada penurunan ketegangan itu dalam bentuk penghindaran atas ketidaksenangan (avoidance of unpleasure) dan selanjutnya menimbulkan kesenangan (production of pleasure). ${ }^{2}$

Freud mengakui kebahagiaan merupakan sesuatu yang sulit diwujudkan. Hal ini mengingat bahwa kehidupan dirasa terlalu berat karena banyaknya penderitaan, kekecewaan, dan kemustahilan. Ketika seseorang merasakan kebahagiaan, sesungguhnya hal tersebut hanyalah pengalihan atas penderitaan-penderitaan yang dialami. Freud menganggapnya sebagai: (a) pembelokan sangat kuat yang menyebabkan seseorang menganggap ringan penderitaannya; (b) kepuasan pengganti, yang akan mengurangi penderitaan tersebut; dan (c) substansi-substansi memabukkan (seperti dalam psikotropika) yang membuat seseorang tidak mengindahkan penderitaannya. ${ }^{3}$ Freud menawarkan 2 metode untuk meraih kebahagiaan, yaitu hubungan emosional dengan orang lain dan kesenangan atas keindahan. ${ }^{4}$

\section{Psikologi Humanistik}

\section{a. Piramida Kebutuhan (Hierarchy of Needs)}

Kaitannya dengan konsep kebahagiaan, Abraham Maslow, sebagai bapak psikologi humanistik, mengajukan teori "piramida kebutuhan" (hierarchy of needs) sebagai dasar peningkatan kebahagiaan manusia. Asumsinya, untuk meraih kebahagiaan diperlukan adanya beberapa prasyarat yang harus dipenuhi. 
ROFI'UDIN: Konsep Kebahagiaan...

Prasyarat itu merupakan suatu kebutuhan asasi manusia yang jika dipenuhi akan menciptakan kebahagiaan.

Maslow menjelaskan kebutuhan dasar manusia terdiri atas lima tingkatan, yaitu: (a) kebutuhan fisiologis, (b) kebutuhan keamanan, (c) kebutuhan cinta dan kepemilikan, (d) kebutuhan penghargaan, dan (e) kebutuhan aktualisasi diri. ${ }^{5}$ Jika kebutuhankebutuhan tersebut terpenuhi, maka kebahagiaan relatif akan lebih mudah diraih.

\section{b. Logoterapi}

Victor Frankl memperkenalkan "logoterapi" sebagai teknik memaknai kehidupan dan mencapai kebahagiaan.Ia menawarkan tiga cara untuk meraih makna hidup, yaitu (1) melalui tindakan; (2) melalui pengalaman berharga dalam berbagai medium (keindahan seni, cinta relasional, dan sebagainya); dan (3) melalui penderitaan. ${ }^{6}$

Frankl mengembangkan teknik yang terakhir ini berdasarkan pengalamannya lolos dari kamp konsentrasi Nazi pada masa Perang Dunia II, di mana ia mengalami dan menyaksikan penyiksaanpenyiksaan di kamp tersebut. Ia menyaksikan dua hal yang berbeda, yaitu para tahanan yang putus asa dan para tahanan yang memiliki kesabaran luar biasa serta daya hidup yang perkasa. Frankl menyebut hal ini sebagai kebebasan seseorang memberi makna pada hidupnya. Teknik mencari makna dengan penderitaan dilakukan ketika teknik pertama dan kedua tidak dapat dilakukan.

\section{Psikologi Transpersonal}

Psikologi transpersonal seperti halnya psikologi humanistik, menaruh perhatian pada dimensi spiritual manusia yang ternyata mengandung berbagai potensi dan kemampuan luar biasa yang sejauh ini terabaikan dari telaah psikologi kontemporer. Bedanya adalah psikologi humanistik lebih memanfaatkan potensi-potensi ini untuk meningkatkan hubungan antar manusia, sedangkan psikologi transpersonal lebih tertarik untuk meneliti pengalaman subjektif 
ROFI'UDIN: Konsep Kebahagiaan...

transendental, serta pengalaman luar biasa dari potensi-potensi spiritual ini. ${ }^{7}$

Psikologi transpersonal memandang manusia dari dua segi: potensi-potensi luhur (the highest potential) dan fenomena kesadaran (state of consciousness) manusia. Psikologi transpersonal mencoba melakukan penelitian terhadap suatu dimensi yang sejauh ini lebih dianggap sebagai garapan kaum rohaniawan kebatinan, agamawan dan mistikus. Psikologi transpersonal menunjukkan bahwa di luar kesadaran biasa, terdapat ragam dimensi lain yang luar biasa dan mampu mengembangkan potensi-potensi luhur yang dimiliki manusia. ${ }^{8}$ Dengan demikian, kebahagiaan transpersonal diraih dengan pengembangan potensi-potensi luhur dan kesadaran atas kesatuan kosmis tersebut.

\section{Psikologi Positif}

Psikologi positif memiliki tiga konsep utama dalam isu kebahagiaan. Pertama, pengalaman subyektif yang positif, seperti kesejahteraan, ketertarikan, kegembiraan, optimisme, dan harapan. Kedua, karakter kepribadian pada individu yang sedang tumbuhkembang, khususnya kekuatan dan kebaikan, seperti keberanian, ketekunan, pikiran terbuka, dan kearifan. Dan ketiga, tingkat psikologi sosial dalam mengidentifikasi, mempelajari, dan meningkatkan kualitas institusi sosial dalam menopang pengalaman subyektif yang positif dan karakter kepribadian yang adaptif.9

Martin Seligman menyebut kebahagiaan yang otentik (authentic happiness) dibagi ke dalam tiga dimensi: 1) kesenangan dan kepuasan, 2) perwujudan dari kekuatan dan kebajikan, dan 3) makna dan tujuan. Mihaly Csikszentmihalyi, seorang psikolog asal Hongaria, dalam studinya tentang "flow"10 menjelaskan bahwa kebahagiaan bukanlah kondisi yang telah ditetapkan, tetapi ia dapat dikembangkan dengan belajar untuk mencapai flow dalam hidup. Flow dimaknai sebagai suatu keterhanyutan, hobi, atau penyaluran bakat dan minat sehingga memberikan kesenangan bagi seseorang.

TEOLOGIA, VOLUME 24, NOMOR 2, JULI-DESEMBER 2013 
Seorang pelopor psikologi positif lainnya, Ed Diener, menyatakan bahwa kebahagiaan dapat diukur secara empiris. Diener menyebutnya "kesejahteraan subyektif" (subjective well-being), yaitu suatu konsep kasar yang mencakup pengalaman emosi yang menyenangkan, rendahnya perasaan negatif, serta tingginya kepuasan hidup. ${ }^{11}$

\section{Bagan Kebahagiaan dalam Psikologi dan Tasawuf}

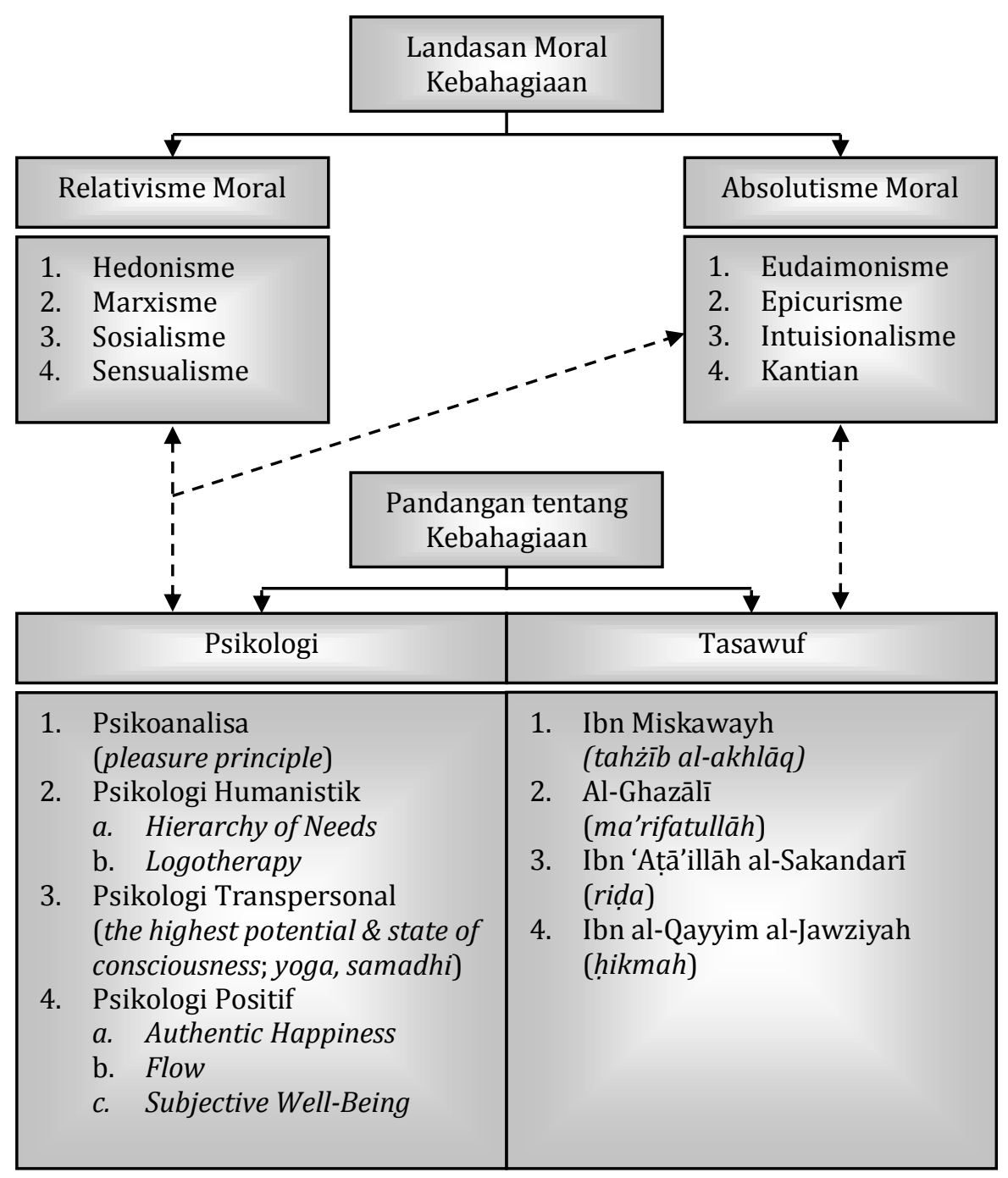


ROFI'UDIN: Konsep Kebahagiaan...

\section{Metode Psikologi Sufistik}

Psikologi Islam memiliki kedudukan yang sama dengan disiplin ilmu keislaman yang lain, seperti sosiologi Islam, ekonomi Islam, dan sebagainya. Penggunaan kata "Islam" di sini memiliki arti corak, cara pandang, pola pikir, paradigma, atau aliran-aliran tersendiri yang berbeda dengan psikologi kontemporer pada umumnya. Psikologi Islam tidak hanya menekankan perilaku kejiwaan, melainkan juga hakikat jiwa sesungguhnya. Sebagai satu organisasi permanen, jiwa manusia bersifat potensial yang aktualisasinya dalam bentuk perilaku sangat tergantung pada ikhtiarnya.

Beberapa pendekatan yang dilakukan di dalam membangun psikologi Islam sebagaimana yang pernah dilakukan oleh para psikolog muslim di masa klasik adalah pendekatan skriptualis, pendekatan filosofis dan pendekatan sufistik. ${ }^{12}$ Dengan demikian, psikologi sufistik sendiri merupakan psikologi Islam yang memiliki karakteristik dan pendekatan sufistik.

Dalam metode operasionalnya, Abdullah Hadziq setidaknya mencatat 4 metode yang digunakan dalam psikologi sufistik, ${ }^{13}$ yaitu:

\section{Metode Mulāḥaḍah Țabīiyah}

Metode ini dimaksudkan untuk memperoleh hal-hal yang terkait dengan tingkah laku manusia secara sadar, sistematis dengan tujuan sesuai yang telah direncanakan.Mulāhaḍah tabỉizyah sebagai suatu metode dapat digunakan untuk mempelajari jiwa seseorang melalui gejala perilaku yang diamati, karena dalam pandangan psikologi agama, tingkah laku seseorang yang nampak secara lahiriah lebih banyak dipengaruhi oleh keyakinan yang dianutnya atau kerangka pikir teologi yang mendasarinya.

\section{Metode Tajrīb Rūhạānī}

Metode tajrīb rūhānī ini merupakan metode eksperimen dalam situasi khusus yang bernuansa spiritual, dimana gejala-gejala yang

TEOLOGIA, VOLUME 24, NOMOR 2, JULI-DESEMBER 2013 
ROFI'UDIN: Konsep Kebahagiaan...

diteliti disederhanakan sedemikian rupa, sehingga peneliti dapat menguasai seluruh proses eksperimen yang ada. Metode ini dimaksudkan untuk mengetahui ada tidaknya hubungan sebab akibat antara usaha-usaha yang bersifat spiritual dengan tingkah laku keseharian pada objek yang dijadikan uji coba.

\section{Metode Interpretasi Kitab Suci}

Munculnya metode interpretasi kitab suci ini, dilatarbelakangi oleh suatu fakta bahwa dasar-dasar objek keilmuan psikologi sufistik dirumuskan atas kerangka pikir kitab suci sebagai referensi utamanya. Hal ini dapat diperhatikan pada pemikiran-pemikiran psikologinya tentang nafs, 'aql, qalb, rūh, dan fitrah.

\section{Metode Kasyf}

Maksudnya adalah metode pemahaman tentang apa yang tertutup bagi pemahaman rasional dan sensual, yang tersingkap bagi seseorang seakan-akan dia melihat dengan mata telanjang. ${ }^{14}$ Cara intuitif ini, sekalipun dalam wacana tertentu dikategorikan sebagai pendekatan "non ilmiah", tetapi keberadaannya masih bisa diakui sebagai metode untuk memperoleh kebenaran/pengetahuan. ${ }^{15}$

Hal ini sejalan dengan pandangan al-Ghazālī yang menyatakan bahwa metode kasyf (intuitif) masih dapat dibenarkan sebagai sarana untuk memperoleh bahan pengetahuan, selama pengetahuan yang dihasilkan tidak berlawanan dengan prinsip-prinsip agama. ${ }^{16}$ Untuk memperoleh pengetahuan intuitif melalui metode kashf, subjek pencari pengetahuan ini, disyaratkan terlebih dahulu melakukan mujāhadah dan riyạ̣̄ah, dengan melewati tahapan demi tahapan (maqāmāt) yang telah ditentukan. ${ }^{17}$

\section{Metode Sufistik Meraih Kebahagiaan}

Dalam tasawuf, para ulama menyusun suatu sistem yang dapat digunakan untuk mencapai kebahagiaan tertinggi. Sistem ini 
ROFI'UDIN: Konsep Kebahagiaan...

merupakan dasar didikan dalam latihan ruhani (riyāḍah) bagi para sufi yang tersusun dalam tiga tingkat takhallī, tahallī, dan tajallī.18

\section{Takhallī}

Takhallī merupakan upaya seseorang membersihkan dirinya dari sifat-sifat tercela, kotoran hati, maksiat lahir dan batin. Upaya ini merupakan langkah awal seseorang dalam menempuh tasawuf, karena sifat-sifat tercela tersebut merupakan pengganggu dan penghalang utama manusia dalam berhubungan dengan Allah.

Dasar ajaran takhallī ini adalah firman Allah:

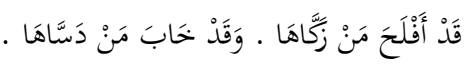

Sungguh beruntunglah orang yang mensucikan jiwa itu, dan sungguh merugilah orang yang mengotorinya. ${ }^{19}$

Sifat-sifat tercela merupakan maksiat lahir, yaitu segala perbuatan yang dikerjakan anggota badan yang akibatnya merusak diri sendiri maupun orang lain, sehingga membawa korban harta benda, pikiran, dan perasaan. Adapun maksiat batin lebih berbahaya lagi, karena ia tidak kelihatan dan kurang disadari sehingga sukar menghilangkannya. Maksiat batin inilah sesungguhnya yang menggerakkan maksiat lahir.Selama maksiat batin belum bersih selama itu pula maksiat lahir tiap saat dapat terulang, bahkan menimbulkan jenis maksiat yang lebih banyak.Kedua jenis maksiat tersebut, lahir dan batin, tidak diragukan lagi selalu mengganggu keselamatan, kesejahteraan, dan kebahagiaan hidup manusia.Sebab maksiat itu mengotori jiwa manusia sehingga menjadikan hijab yang membatasi dirinya dengan Allah.

Untuk membuka hijab tersebut, para ulama tasawuf memberkan beberapa jalan yang harus ditempuh, yaitu ${ }^{20}$ :

\section{a. Mensucikan diri dari najis dan hadats}

Cara ini dilakukan dengan beristinja', baik dengan air atau tanah. Bila berhadats besar dilakukan dengan mandi, dan bila hadats kecil 
ROFI'UDIN: Konsep Kebahagiaan...

dengan wudlu. Intinya, seseorang yang hendak berhubungan dengan Allah harus bersih dan suci badannya, pakaiannya, tempatnya, lahir dan batinnya.

\section{b. Mensucikan diri dari dosa lahir}

Ada tujuh anggota badan yang membuat dosa lahir dan harus disucikan, yaitu:

1) Mulut yang biasa berdusta dan ghibah

2) Mata yang biasa melihat yang haram

3) Telinga yang biasa mendengar cerita bohong

4) Hidung yang biasa menimbulkan rasa benci

5) Tangan yang biasa merusak

6) Kaki yang biasa berjalan berbuat maksiat

7) Kemaluan yang biasa bersyahwat dan berzina (termasuk perut yang biasa diisi dengan barang haram)

\section{c. Mensucikan diri dari dosa batin}

Mensucikan diri dari dosa batin dilakukan dengan cara berzikir.Ulama tasawuf menjelaskan 7 macam zikir untuk mensucikan diri dari dosa batin, yaitu:

1) Lațīfah al-Qalb, letaknya dua jari di bawah susu kiri, berhubungan dengan jantung jasmani. Di sini letaknya sifatsifat syirik, kufur, tahayul, dan sifat-sifat iblis. Untuk mensucikannya dengan berzikir membaca "Allah" sebanyak 5000 kali. Pada tingkat ini, hati diisi dengan iman, Islam, ihsan, tauhid, dan makrifat. Cahaya latîfah ini berwarna kuning, dan bila cahaya tersebut keluar dari depan pundak dan melaju ke atas, atau padanya diperoleh getaran atau gerakan kuat, tuntunlah dengan lațifah al-rūh.

2) Lațîfahal-rūh, letaknya dua jari di bawah susu kanan, berhubungan dengan rabu jasmani. Di sinilah letak sifat bahimiyah (binatang jinak), seperti menuruti hawa nafsu. Untuk mensucikannya dengan berzikir membaca "Allah" sekeras-kerasnya sebanyak 1000 kali. Cahaya lațifah ini 
ROFI'UDIN: Konsep Kebahagiaan...

berwarna merah, dan bila cahaya tersebut bergerak atau menyala, tuntunlah dengan latiffah al-sirr.

3) Lațifah al-Sirr, letaknya dua jari di atas susu kiri. Di sinilah letak sifat syabā'iyah (binatang buas), seperti zalim, pemarah, pendendam, dan sebagainya. Untuk mensucikannya dengan berzikir membaca "Allah" sebanyak 1000 kali. Ada pula sifat baiknya, seperti kasih sayang dan ramah. Cahaya lațifahini berwarna putih, dan bila menyala, tuntunlah dengan latîfah al-khafi.

4) Lațifah al-Khafi, letaknya dua jari di atas susu kanan, berhubungan dengan limpa jasmani. Di sinilah letak sifat dengki, khianat, dan sifat-sifat syaithaniyah lainnya. Sifatsifat ini membawa kecelakaan dan kebinasaan dunia dan akhirat. Untuk mensucikannya dengan berzikir membaca "Allah" sekeras-kerasnya sebanyak 1000 kali. Ada pula sifat baiknya, seperti syukur dan sabar. Cahaya lațīfahini berwarna hitam, dan bila menyala, tuntunlah dengan lațifah al-akhfä.Lațifah al-Akhfā, letaknya di tengah dada, berhubungan dengan empedu jasmani. Di sinilah letak sifat rabbāniyah, seperti riya', takabur, ujub, sum'ah, dan sebagainya. Untuk mensucikannya dengan berzikir membaca "Allah" sebanyak 1000 kali. Ada pula sifat baiknya, seperti ikhlas, khusyuk, taḍaru', tawaḍu', tafakur.

5) Lațifah Nafs al-Națiqah, letaknya di antara dua kening. Di sinilah letak nafsu amarah yang selalu mendorong berbuat jahat. Sifat ini yang menjadi penghalang besar untuk perbaikan masyarakat. Dalam lațifah ini juga terdapat sifat jahat seperti banyak hayalan dan panjang angan-angan. Untuk mensucikannya dengan berzikir membaca "Allah" sebanyak 1000 kali. Ada pula sifat baiknya, seperti tenteram dan pikiran tenang.

6) Lațīfah Kulli Jasad, letaknya di seluruh tubuh jasmani. Di sinilah letak sifat-sifat jahl dan ghaflah (kebodohan dan kealpaan). Untuk mensucikannya dengan berzikir membaca "Allah" sebanyak 1000 kali. Hal ini berguna untuk menghilangkan sifat-sifat materialistik sehingga mengalir zikir di sekujur tubuh jasmani dan tidak ada tempat lagi

TEOLOGIA, VOLUME 24, NOMOR 2, JULI-DESEMBER 2013 
ROFI'UDIN: Konsep Kebahagiaan...

sifat-sifat buruk. Ada pula sifat baiknya, seperti ilmu dan amal. ${ }^{21}$

Selain dengan membaca "Allah" seperti zikir di atas, dapat ditempuh pula dengan cara yang lain, seperti membaca "Lā ilāha illallāh". Tata caranya, hendaknya orang yang berzikir menempelkan lidahnya pada langit-langit tenggorokan. Setelah mengambil nafas, tahanlah rongga mulut dan mulailah dengan mengucapkan "Lā" sambil berimajinasi dari bawah pusar dan membentangkannya ke tengah dada (lațīfah akhfā)sehingga berhenti pada lațifah nafs alnațiqah yang berada di bagian dalam otak pertama yang disebut selaput otak (ra'is dimagh).

Setelah itu, mulailah dengan mengucapkan hamzah kalimat "Ilāha" mulai dari otak sambil berimajinasi dan turun hingga berhenti di bahu sebelah kanan, lalu mengalirkannya ke dalam ruh.Setelah itu, mulailah mengucapkan hamzah kalimat "Illallāh" sambil berimajinasi.Dimulai dari bahu dan membentangkannya secara menurun ke ambang tengah dada sehingga bersamanya berhenti di hati.Lalu berimajinasi memukul kehitaman hati dengan lafal Jalalah (Allah) melalui kekuatan nafas yang tertahan sehingga pengaruh dan panasnya terasa pada seluruh tubuh (lațifah kulli jasad).Dengan begitu panasnya menghanguskan seluruh bagian tubuh yang jelek serta bagian-bagian yang baik diterangi dengan cahaya keagungan Allah. ${ }^{22}$

\section{Tahallī}

Taḥallī merupakan upaya seseorang untuk mengisi dengan sifatsifat terpuji, menyinari hati dengan taat lahir dan batin. Tahallī dilakukan setelah seseorang membersihkan diri dari hal-hal yang mengotori jiwanya dari bermacam sifat tercela dan maksiat. Selanjutnya dibarengi dengan penyinaran hati agar hati yang kotor dan gelap menjadi bersih dan terang, karena hati yang demikian itulah yang dapat menerima pancaran cahaya Tuhan. 
ROFI'UDIN: Konsep Kebahagiaan...

Sifat-sifat terpuji yang harus mengisi jiwa itu antara lain adil, belas kasihan, amal saleh, berani, baik sangka, berbudi pekerti luhur, berjiwa kuat, berlaku benar, bijaksana, dapat dipercaya, ikhlas, cinta, manis muka, menghormati tamu, menyimpan rahasia, mencegah kejahatan, pemaaf, pemalu, penyantun, penolong, penunjuk jalan kebenaran, sabar, zuhud dan sebagainya.

Dasar ajaran tahallīadalah firman Allah:

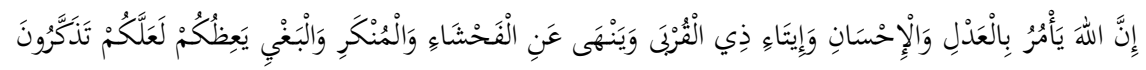

Sesungguhnya Allah menyuruh (kamu) berlaku adil dan berbuat kebajikan, memberi kepada kaum kerabat, dan Allah melarang dari perbuatan keji, kemungkaran dan permusuhan. Dia memberi pengajaran kepadamu agar kamu dapat mengambil pelajaran. ${ }^{23}$

Dalam taḥallī ini, terdapat dua terma yang lazim dipakai dalam menjelaskan tahapan-tahapan yang harus dilalui dan keadaan seorang penempuh jalan spiritual (sālik) dalam usahanya mengisi jiwanya dengan sifat-sifat terpuji, yaitu terma maqāmāt dan aḥwāl.

Maqāmāt menunjukkan "posisi" seseorang dalam perjalanan menuju Allah, dengan memenuhi segala kewajiban berkaitan dengan maqām tersebut dan tetap berada di dalamnya hingga dia memahami kesempurnaannya sejauh itu berada dalam batas kemampuan manusia. Aḥwāl adalah sesuatu yang diturunkan Allah kepada hati manusia yang setitik pun manusia oleh kehendaknya sendiri tidak bisa menolak ketika aḥwāl mendatanginya, atau mempertahankannya ketika aḥwāl beranjak pergi. ${ }^{24}$ Dengan kata lain, aḥwāl atau hạal sifatnya sementara, datang dan pergi bagi seorang sufi dalam perjalanannya mendekati Tuhan. Hāl terkadang datang dalam waktu yang lama dan terkadang hanya sekejap. ${ }^{25}$

\section{Maqāmāt}

Maqāmāt adalah bentuk jamak dari maqām. Maqām secara literal berarti tempat berdiri, stasiun, tempat, lokas, posisi, atau

TEOLOGIA, VOLUME 24, NOMOR 2, JULI-DESEMBER 2013 
ROFI'UDIN: Konsep Kebahagiaan...

tingkatan. Secara terminologis berarti kedudukan spiritual. ${ }^{26}$ Abū Naşr al-Sarrāj mendefinisikan maqāmāt sebagai:

Kedudukan atau tingkatan seorang hamba di hadapan Allah yang diperoleh melalui serangkaian pengabdian (ibadah), kesungguhan melawan hawa nafsu dan penyakit-penyakit hati (mujāhadah), latihan-latihan spiritual (riyāḍah), dan mengarahkan segenap jiwa raga semata-mata kepada Allah serta memutuskan selain-Nya (inqițā' ila Allāh). ${ }^{27}$

Abū Nașr al-Sarrāj, dalam kitabnya al-Luma', menyebutkan 7 maqāmāt yang harus ditempuh oleh sālik, yaitu tawbah, wara', zuhud, faqr, șabar, tawakal,dan riḍa. ${ }^{28}$

1) Tawbah; kembali dari perbuatan-perbuatan yang menyimpang, berjanji untuk tidak mengulanginya kembali, kemudian kembali kepada Allah.

2) Wara'; menjauhkan diri dari dosa dan menahan dari hal-hal yang syubhat dan maksiat.

3) Zuhd; sikap tidak tertarik terhadap dunia dengan cara meninggalkan kehidupan duniawi, tidak terbelenggu oleh hidup kebendaan; mengasingkan diri dari kesenangan dunia untuk ibadah.

4) Faqr; senantiasa merasa butuh kepada Allah.

5) Sabr; memiliki kekuatan jiwa yang cukup agar tetap sabar dalam keadaan sengsara dan menderita, serta tetap gigih di tengah-tengah kesulitan dalam memperjuangkan tujuannya sendiri. Sabar ini ada tiga macam: sabar dalam ketaatan kepada Allah, sabar dari kedurhakaan kepada Allah, dan sabar dalam ujian Allah.

6) Tawakkul; mempercayakan atau menyerahkan segenap masalah kepada Allah sepenuhnya dan menyandarkan kepada-Nya penanganan berbagai masalah yang dihadapi.

7) Rida; sikap menerima dengan lapang dan senang terhadap apapun keputusan dan perlakuan Allah kepada seorang hamba, entah itu menyenangkan atau tidak. 
ROFI'UDIN: Konsep Kebahagiaan...

\section{Aḥwāl}

Ahwwāl adalah jama' dari hăal yang artinya keadaan, yakni keadaan hati yang dalam oleh para sufi dalam menempuh jalan untuk dekat kepada Tuhan. Atau, situasi kejiwaan yang diperoleh seorang sufi sebagai karunia Allah, bukan berasal dari hasil usahanya. Ahwwāl atau hăl merupakan keadaan mental, seperti perasaan senang, sedih, takut, dan sebagainya. Dapat juga diartikan sebagai keadaan-keadaan spiritual sebagai anugerah dan karunia Allah kepada hati para penempuh jalan spiritual.

Abū Naṣr al-Sarrāj menyebutkan ada 10 Aḥwāl yang dirasakan para sālik, yaitu murāqabah, qurb, maḥabbah, khawf, rajā', syawq, uns, țuma'nīnah, musyāhadah, dan yaqīn. ${ }^{29}$

1) Murāqabah; melestarikan pengamatan kepada Allah dengan hatinya, sehingga manusia mengamati pekerjaan dan hukum-hukum-Nya, dan dengan penuh perasaannya, Allah melihat dirinya dalam gerak dan diam.

2) Qurb; penyaksian sang hamba dengan hatinya akan kedekatan Allah kepadanya, maka ia mendekat kepada Allah dengan ketaatannya, dan mengerahkan segenap keinginannya kepada Allah semata dengan cara mengingat-Nya secara kontinyu baik pada saat ramai maupun sendiri.

3) Mạabbah; perwujudan rasa kedekatan jiwa dan raga seorang hamba dihadapan Tuhannya. Walau cinta merupakan masalah asli dalam tasawuf, akan tetapi para arif mengaku bahwa mereka tidak mampu memaknai dan mendefinisikan cinta.

4) Khawf; kegundahan hati dan gerakannya untuk menghindar dari datangnya sesuatu yang tidak disukainya; cambuk Allah yang digunakan-Nya untuk menghukum manusia yang berontak keluar dari ambang pintu-Nya.

5) Raja; melihat kegemilangan Ilahi dengan kemurahan Tuhan.

6) Syawq; pengetahuan dan pengenalan yang mendalam terhadap Allah akan menimbulkan rasa senang dan gairah.

TEOLOGIA, VOLUME 24, NOMOR 2, JULI-DESEMBER 2013 
ROFI'UDIN: Konsep Kebahagiaan...

7) Uns; perbincangan ruh dengan Sang Kekasih pada kondisi sangat dekat.

8) Tuma'nīnah; tidak ada rasa was-was atau khawatir, tidak ada yang dapat mengganggu perasaan dan pikiran, karena telah mencapai tingkat kebersihan jiwa yang paling tinggi.

9) Musyāhadah; melihat Tuhan dengan mata hati, tanpa keraguan sedikitpun, bagaikan melihat-Nya dengan mata kepala.

10) Yaqīn; perpaduan antara pengetahuan yang luas dan mendalam dengan rasa cinta dan rindu yang menggelora bertaut lagi dengan perjumpaan secara langsung, tertanamlah dalam jiwanya dan tumbuh bersemi perasaan yang mantap, itulah yaqin.

\section{Tajallī}

Tajallī inilah yang sesungguhnya dinanti para penempuh jalan spiritual untuk meraih kebahagiaan yang diidam-idamkan. Tajalli adalah merasakan adanya rasa ketuhanan yang sampai pada kenyataan ketuhanan, yakni lenyapnya hijab dari sifat-sifat kemanusiaan ketika tampak wajah Allah. Dasar tajallī ini adalah firman Allah:

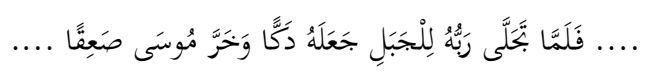

...Tatkala Tuhannya menampakkan diri (tajallī) kepada gunung itu, dijadikannya gunung itu hancur luluh dan Musa pun jatuh pingsan .....30

Dalam tajallī terdapat 4 tingkatan, yaitu tajallī af âl, tajallī asmā', tajallīṣifāt, dan tajallīżāt. Semua tingkatan tajallī merupakan perwujudan fana' dari seorang hamba dalam baqa' Allah, artinya leburnya seorang hamba di bawah pancaran cahaya Allah.

1) Tajallī Af'āl (Perbuatan); lenyapnya perbuatan dari seorang hamba dan yang ada hanya perbuatan Allah semata. 
ROFI'UDIN: Konsep Kebahagiaan...

2) Tajallī Asmā' (Nama); lenyapnya seorang hamba dari dirinya sendiri, bebasnya ia dari sifat-sifat ke-huduth-an, dan lepasnya ikatannya dari tubuh kasarnya, ketika ia fana' dalam baqa' Allah karena telah sucinya ia dari sifat-sifat kehuduth-an.

3) Tajallīîifāt (Sifat); ibarat penerimaan tubuh seorang hamba atas sifat-sifat ketuhanan, sebagai penerimaan yang asli dan suatu ketentuan yang pasti. Ketika seorang hamba menerima sifat sama' Allah, ia dapat mendengar semua wujud yang dapat bersuara, seperti binatang, kayu, batu, dan sebagainya.

4) TajallīŻāt (Zat); ketika Allah menghendaki tajallī atas hamba-Nya yang memfana'kan dirinya sehingga Allah memberinya karunia ketuhanan (lațīfah al-ilāhiyah). Ketika itu terjadi pada seorang hamba, maka terjadilah "Tunggal yang Sempurna" (al-Fard al-Kāmil) yang menjadikan seorang hamba berada dalam situasi māsiwāllāh, tiada wujud secara mutlak kecuali Allah (lā maujud 'ala al-ițlāq illallāh).

Proses tajallī, sebenarnya, dimulai dari tajalliżāt pada sifat-sifat dan asmā', kemudian pada perbuatan-perbuatan, sehingga memunculkan alam semesta. Akan tetapi, dalam rangka meningkatkan martabat ruhani, tajallī tersebut ditempatkan dengan urutan terbalik, dimulai dari tajallī perbuatan-perbuatan dan berakhir pada tajallīzat. Pemutarbalikan itu bukan tidak beralasan, tetapi didasarkan atas pandangan bahwa tajallī al-afāal yang paling dekat dengan kenyataan empiris, sedangkan tajalliżāt merupakan yang paling abstrak dan jauh dari kenyataan. Maka untuk mendekatkan diri haruslah dimulai dari yang terdekat menuju yang jauh dan amat abstrak.

TEOLOGIA, VOLUME 24, NOMOR 2, JULI-DESEMBER 2013 


\section{Bagan Hubungan Potensi Ruhani dan Perbuatan Manusia}

(Paryana Suryadipura, Alam Pikiran, 1963)

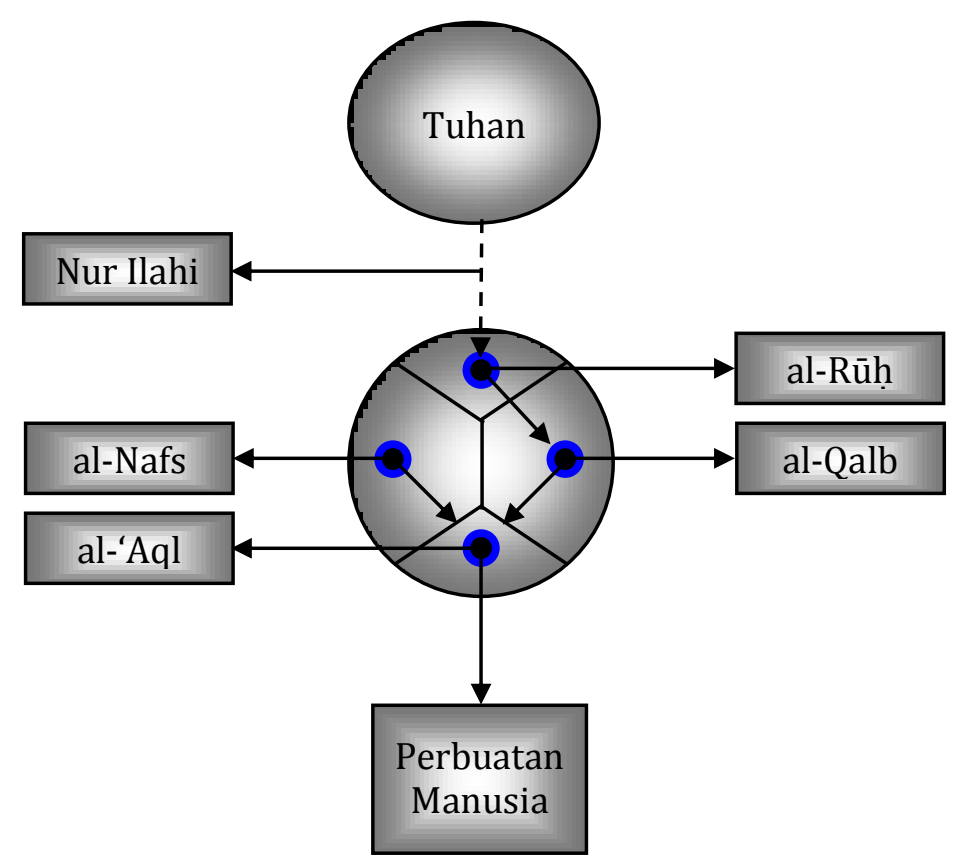

\section{Tarekat: Jalan Sufi Menuju Kebahagiaan}

Kaum sufi yang bertujuan mencari Tuhan menyebut dirinya sebagai pengembara (sālik). Ia melakukan pengembaraan (sulūk) dengan perlahan-lahan melalui tahapan-tahapan (maqāmāt) tertentu setelah melewati jalan (țariqah) guna mencapai tujuan untuk bersatu dengan kenyataan (fanā' fi al-Haq). Masing-masing sufi dalam pengembaraannya bisa jadi menemukan "peta perjalanan ruhani" yang tidak sama seperti sufi sebelumnya. ${ }^{31}$

Dalam khazanah tasawuf, pencarian atas hakikat (haqiqah) diibaratkan dengan pengembaraan (sulūk) seorang sālik dalam mencari mutiara haqīqah di lautan syari'at (syarīah). Untuk mendapatkan mutiara yang terpendam di dasar lautan syariat 
ROFI'UDIN: Konsep Kebahagiaan...

tersebut, dibutuhkan perahu atau jalan (țariqah, tarekat) dengan penunjuk jalan atau nahkoda seorang guru (shaykh). Seorang shaykh penunjuk jalan (mursyīd) adalah pemandu jalan yang aman bagi seorang murīd (orang yang berkehendak) dalam melakukan perjalanan spiritual menuju Allah. Pentingnya murshid bagi seorang murīd ditunjukkan oleh al-Qur'an sebagai berikut:

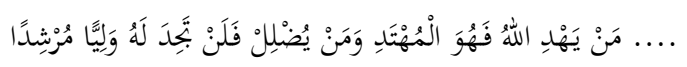

.... Barangsiapa yang diberi petunjuk oleh Allah, maka dialah yang mendapat petunjuk; dan barangsiapa yang disesatkanNya, maka kamu tidak akan mendapatkan seorang pemimpin pun yang dapat memberi petunjuk (murshid) kepadanya. ${ }^{32}$

Ayat tersebut dapat dipahami bahwa orang yang tidak memiliki guru mursyid yang dapat membimbingnya pada Allah, maka Allah tidak hendak memberinya petunjuk, bahkan ia akan tersesat. Dengan kata lain, orang yang menempuh perjalanan menuju Allah tanpa adanya pembimbing spiritual akan tersesat, sebab mursyid adalah orang yang pernah sampai (wuṣūl) kepada Allah, sehingga mengetahui jalan (țaīqah) yang benar.

Para mursyid memiliki jalan yang tidak sama dalam upaya wușūl kepada Allah. Mereka memiliki sistem dan metode yang beragam antara mursyid satu dengan lainnya. Di kemudian hari, sistem dan metode tersebut berkembang menjadi organisasi tasawuf yang disebut tarekat. Berdirinya tarekat tidak dapat dilepaskan dari metode para pendirinya dalam perjalanannya yang telah sampai kepada Allah.

Tarekat adalah kelompok-kelompok pengikut ajaran tasawuf yang menekankan praktik-praktik ibadah dan zikir secara kolektif yang diikat oleh aturan-aturan tertentu, di mana aktifitasnya bersifat duniawi dan ukhrawi. Dengan kata lain, ia dapat dipahami sebagai suatu hasil pengalaman dari seorang sufi yang diikuti oleh para murid, menurut aturan/cara tertentu yang bertujuan untuk lebih mendekatkan diri kepada Allah. Pengalaman sufi berupa tata cara zikir, riyādah, doa-doa yang telah diamalkan dan menurutnya-

TEOLOGIA, VOLUME 24, NOMOR 2, JULI-DESEMBER 2013 
ROFI'UDIN: Konsep Kebahagiaan...

sangsufi-telahberhasil mendekatkan diri sang sufi kepada Tuhan, inilah yang disusun sedemikian rupa menjadi aturan/tata cara yang baku, yang juga harus diikuti oleh murid-murid tarekat. ${ }^{33}$

Pada mulanya tarekat hanya berarti jalan menuju Tuhan yang ditempuh seorang sufi secara individual. Akan tetapi, kemudian sufisufi besar mengajarkan tarekatnya kepada murid baik secara individual maupun secara berkelompok. Dengan demikian tarekat pun berarti jalan menuju Tuhan di bawah bimbingan guru. Selanjutnya mereka melakukan latihan bersama di bawah bimbingan guru. Inilah asal pengertian tarekat sebagai nama sebuah organisasi sufi. Mulai di abad ke-12 Masehi, tarekat menjadi kegiatan yang sifatnya kelembagaan atau organisasi sehingga di kalangan umat Islam muncul penerapan jenis aliran tarekat yang masing-masing mempunyai latar belakang, sejarah, dan cara sendiri-sendiri. Seperti tarekat Qādiriyah, Naqsyabandiyah, Rifā'iyah, Ahmadiyah, Syāżiliyah dan lain-lain. ${ }^{34}$

Tata cara pelaksanaan tarekat antara lain :

1. Zikir, yaitu ingat yang terus menerus kepada Allah dalam hati secara menyebutkan namanya dengan liasan, zikir ini berguna sebagai alat kontrol bagi hati, ucapan dan perbuatan agar tidak menyimpang dari garis yang sudah ditetapkan Allah.

2. Ratib, yaitu mengucapkan lafal "La Illaha Illallah" dengan gaya, gerak dan irama tertentu.

3. Musik, yaitu dalam membacakan wirid-wirid dan syair-syair tertentu diiringi dengan bunyi-bunyian (instrumental) seperti memukul rebana.

4. Menari, yaitu gerak yang dilakukan mengiringi wirid-wirid dan bacaan tertentu untuk menimbulkan kehidmatan.

5. Bernafas, yaitu mengatur cara bernafas pada waktu melakukan zikir tertentu. Untuk mencapai tujuan tarekat sebagaimana disebutkan di atas, perlu mengadakan latihan batin, riyādah dan mujāhadah (perjuangan kerohanian). Perjuangan seperti itu dinamakan pula sulūk dan yang mengerjakannya di sebut sālik.35 
Bagan Kebahagiaan Konseptual dan Operasional dalam Psikologi Sufistik

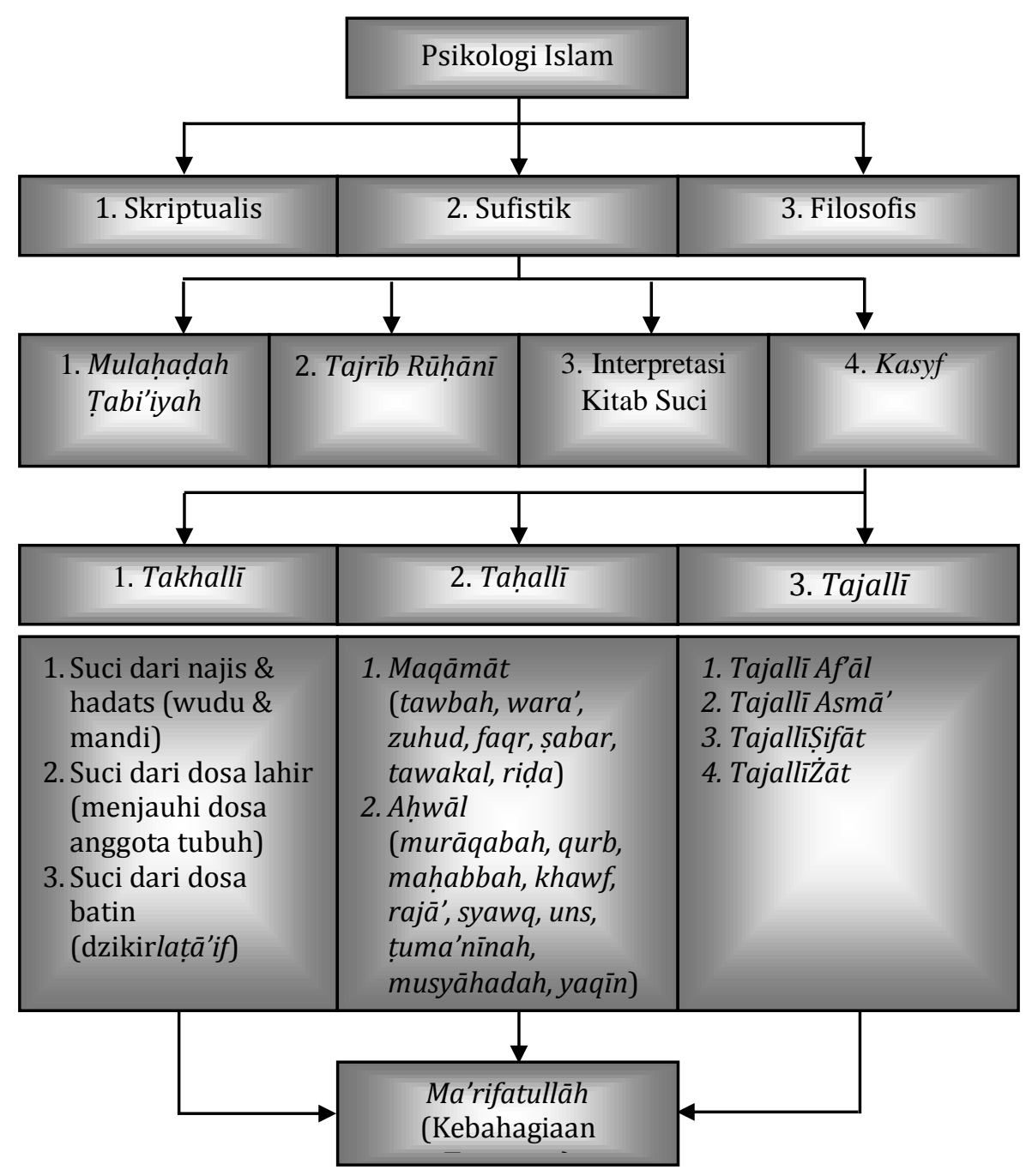

TEOLOGIA, VOLUME 24, NOMOR 2, JULI-DESEMBER 2013 


\section{Kebahagiaan dalam Angka}

\section{Human Development Index (HDI)}

Kesejahteraan merupakan salah satu indikator kebahagiaan. UNDP (United Nations Development Programme), suatu badan PBB yang bergerak dalam bidang pembangunan manusia, mengaitkan kesejahteraan manusia ke dalam suatu indeks pembangunan manusia yang disebut dengan Human Development Index (HDI). HDI merupakan suatu indeks gabungan yang mengukur rerata capaian dalam tiga dimensi dasar pembangunan manusia, yaitu usia harapan hidup dan kesehatan, akses pengetahuan, dan standar kehidupan yang layak. ${ }^{36}$

Peta berikut menunjukkan posisi HDI negara-negara di dunia berdasarkan data UNDP 2011:

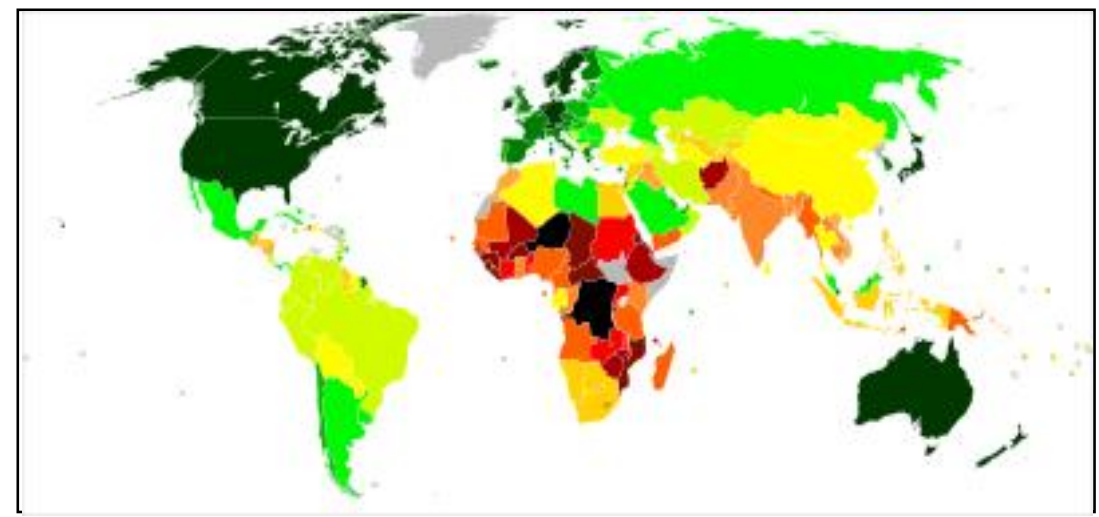

World map indicating theHuman Development Index (based on 2011 data, published on Nov 2, 2011).

0.900 and over

$0.850-0.899$

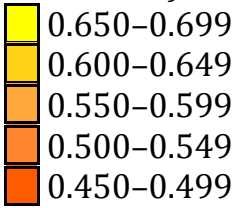

$0.400-0.449$

$0.350-0.399$

$0.300-0.349$

$0.750-0.799$

under 0.300

0.700-0.749

Data unavailable 
ROFI'UDIN: Konsep Kebahagiaan...

Tabel berikut menunjukkan HDI beberapa negara di dunia ${ }^{37}$ :

\begin{tabular}{|c|l|c|c|c|c|}
\hline No & \multicolumn{1}{|c|}{ Country } & HDI & $\begin{array}{c}\text { Life Exp. } \\
\text { (years) }\end{array}$ & $\begin{array}{c}\text { Education } \\
\text { (years) }\end{array}$ & $\begin{array}{c}\text { GNI } \\
\text { (US\$) }\end{array}$ \\
\hline 1 & Norway & 0,943 & 81,1 & 12,6 & 47.557 \\
\hline 2 & Australia & 0,929 & 81,9 & 12,0 & 34.431 \\
\hline 3 & Netherlands & 0,910 & 80,7 & 11,6 & 36.402 \\
\hline 4 & United States & 0,910 & 78,5 & 12,4 & 43.017 \\
\hline 5 & New Zealand & 0,908 & 80,7 & 12,5 & 23.737 \\
\hline 6 & Canada & 0,908 & 81 & 12,1 & 35.166 \\
\hline 7 & Ireland & 0,908 & 80,6 & 11,6 & 29.322 \\
\hline 8 & Liechtenstein & 0,905 & 79,5 & 10,3 & 83.717 \\
\hline 124 & Indonesia & 0,617 & 69,4 & 5,8 & 3.716 \\
\hline 187 & Dem. Rep. Congo & 0,286 & 48,4 & 3,5 & 280 \\
\hline
\end{tabular}

Secara umum, indeks PBB itu menggambarkan, bila manusia hidup lebih lama, menghasilkan uang lebih banyak, dan punya akses pendidikan dan jaminan kesehatan yang bisa diandalkan, maka dia akan hidup relatif lebih bahagia, ketimbang yang tidak memiliki akses.

\section{Paradoks HDI dalam Studi Kebahagiaan}

Studi tentang kebahagiaan, salah satunya dilakukan oleh Adrian White dalam Global Projection of Subjective Well-Being (GPSWB). Studi ini mengkorelasikan ketiga komponen kebahagiaan, yaitu kesehatan, kekayaan, dan akses atas pendidikan, sama seperti indikator HDI.

White menganalisis lebih dari 100 studi yang melibatkan 80.000 orang dan dikelola oleh organisasi seperti UNESCO, CIA, WHO, Latin Barometer, dan Afrobarometer. Dalam analisisnya tersebut, diketahui level kebahagiaan suatu negara diasosiasikan dengan level kesehatan, kekayaan, dan pendidikan. ${ }^{38}$ 
ROFI'UDIN: Konsep Kebahagiaan...

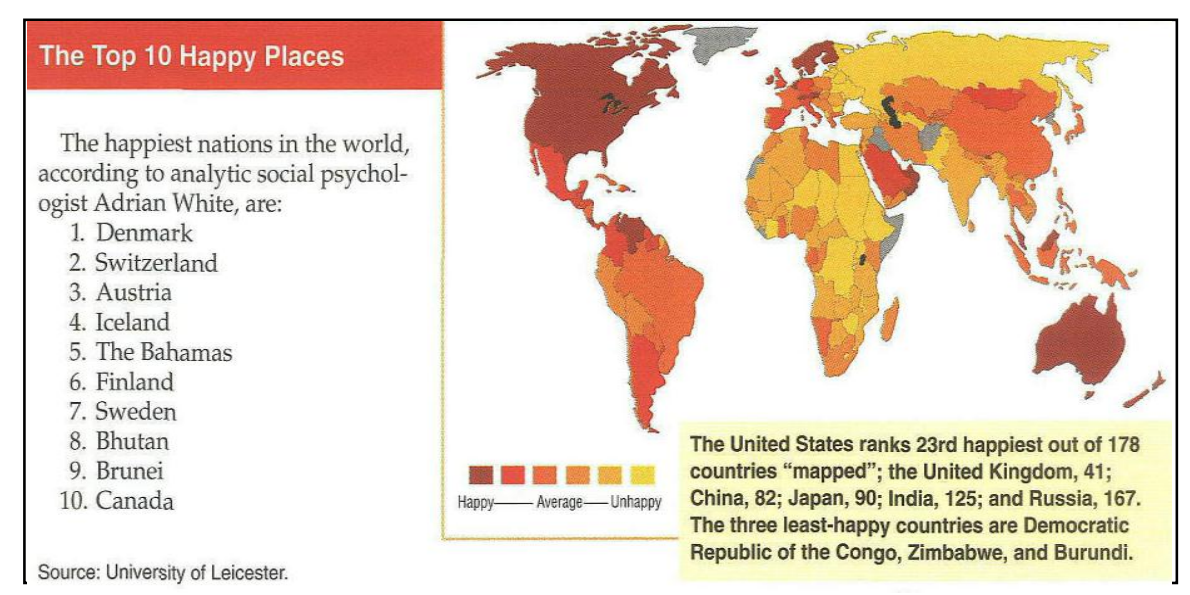

Hasil penelitian tersebut cukup mencengangkan mengingat meski menggunakan indikator yang sama dengan HDI, tetapi hasilnya sangat berbeda. Tabel berikut menggambarkan hal tersebut:

Tabel Paradoks SWB dalam HDI

\begin{tabular}{|c|c|c|c|c|c|c|}
\hline \multirow[b]{2}{*}{ No } & \multirow[b]{2}{*}{ Negara } & \multicolumn{3}{|c|}{ HDI Components } & \multirow{2}{*}{$\begin{array}{c}\text { HDI } \\
\text { Score }\end{array}$} & \multirow{2}{*}{$\begin{array}{l}\text { SWB } \\
\text { Rank }\end{array}$} \\
\hline & & $\begin{array}{l}\text { Life } \\
\text { Exp. }\end{array}$ & $\begin{array}{c}\text { Educa- } \\
\text { tion }\end{array}$ & $\begin{array}{c}\text { GNI } \\
\text { (US\$) }\end{array}$ & & \\
\hline 1 & Norway & 81,1 & 12,6 & 47.557 & 0,943 & 19 \\
\hline 2 & Australia & 81,9 & 12 & 34.431 & 0,929 & 26 \\
\hline 3 & Netherlands & 80,7 & 11,6 & 36.402 & 0,910 & 15 \\
\hline 4 & United States & 78,5 & 12,4 & 43.017 & 0,910 & 23 \\
\hline 5 & New Zealand & 80,7 & 12,5 & 23.737 & 0,908 & 18 \\
\hline 6 & Canada & 81,1 & 12,1 & 35.166 & 0,908 & 10 \\
\hline 7 & Ireland & 80,6 & 11,6 & 29.322 & 0,908 & 11 \\
\hline 8 & Liechtenstein & 79,6 & 10,3 & 83.717 & 0,905 & $*$ ) \\
\hline 124 & Indonesia & 69,4 & 5,8 & 3.716 & 0,617 & 64 \\
\hline 178 & Dem. Rep. Congo & 48,4 & 3,5 & 280 & 0,286 & 176 \\
\hline
\end{tabular}

*) tidak termasuk dalam survei

**) Data diolah dari Human Development Report 2011 dan Global Projection of Subjective Well-Being by Adrian White, 2007

Melihat data di atas, Australia dan Amerika Serikat dapat dijadikan suatu contoh yang sangat jelas dalam paradoks ini. Australia 
ROFI'UDIN: Konsep Kebahagiaan...

menempati posisi kedua dengan HDI 0,929, namunposisinya dalam peta kebahagiaan dunia hanya menempati peringkat 26.Demikian juga dengan Amerika Serikat dengan HDI 0,910 atau peringkat ke-4 dunia, hanya menempati posisi ke-23 dalam hal kebahagiaan penduduknya.

Dengan membandingkan data dari HDI dan "Peta Kebahagiaan Dunia" di atas, terlihat disparitas tingkat HDI dengan kebahagiaan. Tinggi rendahnya HDI tidak menjamin kebahagiaan penduduk suatu negara, meski hal itu merupakan indikator penting guna mengukur dan menganalisis kebijakan pembangunan manusia. Usia harapan hidup, pendidikan, dan pendapatan yang tinggi suatu negara tidak otomatis berbanding lurus dengan kebahagiaan mereka. Demikian sebaliknya, komponen HDI yang rendah dari suatu negara tidak lantas menjadikan penduduknya tidak dapat merasakan kebahagiaan secara layak.

Fakta di atas menunjukkan bahwa persoalan kebahagiaan tidak hanya sebatas angka harapan hidup dan kesehatan, akses pendidikan, dan pendapatan, tetapi menyangkut persoalan prinsip lainnya. Dengan demikian dapat dikatakan bahwa kategorisasi HDI tidak signifikan berpengaruh terhadap kebahagiaan suatu negara.

Hal ini dikuatkan oleh hasil penelitian Diener yang melaporkan bahwa tidak ada hubungan yang signifikan antara tingkat pendapatan (SWB \& HDI) dan kebahagiaan. Ia mencontohkan, lebih dari 50 tahun terakhir pendapatan Amerika Serikat terus mengalami kenaikan, dengan produk domestik bruto (PDB) per kapita naik tiga kali lipat, namun kepuasan hidup penduduknya hampir datar. ${ }^{39}$

Selain itu, faktor keamanan menjadi faktor lain yang menyebabkan "rendahnya" kebahagiaan penduduk Amerika. Reuters, seperti dikutip Antara, melaporkan bahwa pada tahun 2008, Economist Intelligence Unit menyusun "Indeks Perdamaian Global" untuk merangking tingkat keamanan negara-negara di dunia. Hasilnya menempatkan Amerika Serikat pada peringkat yang cukup rendah,

TEOLOGIA, VOLUME 24, NOMOR 2, JULI-DESEMBER 2013 
ROFI'UDIN: Konsep Kebahagiaan...

yakni posisi ke-97 dari 140 negara yang disurvei, sementara Islandia menjadi negara paling aman di dunia, dan Indonesia pada posisi 68. Indeks tersebut berdasarkan penilaian seberapa aman situasi dalam negeri negara bersangkutan dan interaksinya dengan dunia luar. Irak memperoleh peringkat terbawah dalam indeks atau posisi ke-140. Afghanistan juga berada di urutan kelima dari bawah, bersama dengan Sudan, Somalia dan Israel. ${ }^{40}$

Selain itu, beberapa penelitian yang dilakukan menunjukkan tidak signifikannya 3 indikator HDI dalam mempengaruhi tingkat kebahagiaan. Dalam studi lintas budaya menunjukkan bahwa orang bahagia adalah mereka yang optimis, realistis, dan secara sosial terikat dengan dukungan keluarga dan teman. Mereka memiliki rasa percaya diri, spiritualitas, dan keyakinan agama yang tinggi. Mereka berkomitmen atas makna transenden dalam hidup. Uang adalah hal sekunder, sekadar tercukupinya kebutuhan dan kehidupan yang tidak memalukan, serta adanya kesempatan beristirahat dan rekreasi. $^{41}$

Smith dan de Grouchy berpendapat bahwa kebahagiaan tidak terdiri atas uang atau kekayaan. Kekuasaan dan kekayaan menawarkan kesenangan-kesenangan dalam hidup, tetapi jika harus mengorbankan kedamaian dan ketenteraman pikiran, dan jika memperoleh kekayaan menyebabkan keletihan dan kegelisahan, maka kekayaan lebih menyusahkan dari yang sepatutnya, dan justru kontra-produktif. Kebahagiaan tidak diraih dari kekayaan tetapi dengan kesenangan berbuat baik. ${ }^{42}$

Elizabeth Dunn, seorang peneliti pada University of British Columbia, menyatakan bahwa orang yang menghabiskan uangnya untuk orang lain merasa lebih bahagia dari yang menghabiskan uangnya untuk diri sendiri. Dalam eksperimennya, Dunn memberi \$5 sampai \$20 kepada para partisipan. Setengah dari mereka diinstruksikan untuk menghabiskan uang tersebut untuk diri sendiri dan setengahnya lagi untuk orang lain. Hasilnya, partisipan yang berderma mengaku merasa lebih bahagia daripada mereka yang 
ROFI'UDIN: Konsep Kebahagiaan...

tidak. Penemuan ini menunjukkan bahwa perubahan sangat kecil dalam alokasi pembelanjaan sekecil \$5 ternyata cukup untuk memberikan keuntungan nyata berupa kebahagiaan. Dunn menulis, "These findings suggest that very minor alterations in spending allocations-aslittle as \$5-maybe enough to produce real gains in happiness on a given day."43

Sementara itu, Diener berpendapat bahwa kebahagiaan sangat berkorelasi dengan hubungan sosial.Ia menyatakan bahwa karakteristik yang paling menonjol dari 10\% siswa dengan tingkat kebahagiaan tertinggi dan gejala depresi terendah adalah ikatan yang kuat terhadap teman dan keluarga serta komitmen untuk menghabiskan waktu bersama mereka. Ia menulis, "the most salient characteristics shared by the 10\% of students with the highest levels of happiness and the fewest signs of depression were their strong ties to friends and family and commitment to spending time with them." 44

Sementara itu, David Myers berpendapat bahwa hubungan pernikahan turut mempengaruhi tingkat kebahagiaan. Di Amerika Serikat, $40 \%$ orang yang menikah mengaku "sangat bahagia", sedangkan yang tidak pernah menikah hanya 23\%. Ia mengutip pendapat Freud bahwa orang dewasa yang sehat adalah mereka yang dapat mencintai dan bekerja (love and work). ${ }^{45}$ Kepuasan hidup, dengan demikian, ditandai oleh hubungan yang terbuka dan saling mendukung, serta makna komitmen dalam menjalani kehidupan.

Dalam sebuah survei yang dilakukan oleh Associated Press dan MTV ditemukan bahwa agama dan keluarga merupakan dua komponen terkuat yang berkontribusi terhadap kebahagiaan kaum muda di Amerika Serikat. Survei dilakukan terhadap 1.280 responden berusia 13-24 tahun dengan lebih dari 100 pertanyaan tersebut. Hasilnya, responden yang menyatakan agama atau spiritualitas sebagai hal terpenting dalam hidup, 80\% dari mereka mengaku "sangat bahagia". Sementara mereka yang menyatakan keimanan tidak penting, $60 \%$ dari mereka mempertanyakan

TEOLOGIA, VOLUME 24, NOMOR 2, JULI-DESEMBER 2013 
ROFI'UDIN: Konsep Kebahagiaan...

kebahagiaan mereka. Survei tersebut juga merilis 44\% responden mengaku bahwa agama dan spiritualitas sebagai hal yang "sangat penting", 21\% mengaku "cukup penting", 20\% mengaku agama "berperan kecil" dalam hidup mereka, dan 14\% mengaku agama "tidak memiliki peran". 46

Beberapa hasil penelitian $\mathrm{di}$ atas menunjukkan bahwa kebahagiaan tidak hanya ditentukan oleh tinggi rendahnya indikator HDI (kesehatan dan usia harapan hidup, pendidikan, dan pendapatan), tetapi juga faktor lain seperti keamanan, berbuat baik, hubungan sosial (pernikahan, pertemanan, keharmonisan keluarga, hubungan kerja, dan sebagainya), agama atau spiritualitas, dan lainnya. Meski indikator HDI turut berpengaruh terhadap kebahagiaan, tetapi pengaruhnya tidak cukup signifikan. Inilah yang menjadikan adanya paradoks antara tingkat HDI dengan kebahagiaan negara-negara di dunia.

\section{Kebahagiaan Bio-Psiko-Sosial Spiritual}

Sebenarnya, konsep kebahagiaan ideal telah dirumuskan oleh World HealthOrganization (WHO) sebagai kesehatan holistik, dimana di dalamnya mencakup aspek kesehatan biologis, psikologis, dan sosial. WHO merumuskan definisi kesehatan dalam cakupan yang sangat luas, yaitu "keadaan yang sempurna baik fisik, mental maupun sosial, tidak hanya terbebas dari penyakit atau kelemahan/cacat". ${ }^{47}$ Dalam definisi tersebut, sehat bukan sekadar terbebas dari penyakit atau cacat. Orang yang tidak berpenyakit pun tentunya belum tentu dikatakan sehat. Ia semestinya dalam keadaan yang sempurna, baik fisik, mental, maupun sosial.

Namun demikian, kebahagiaan dalam konsep kesehatan holistik dari WHO tersebut nyatanya masih menyisakan persoalan. Dalam hal ini, dimensi spiritual perlu dimasukkan sebagai tolok ukur kebahagiaan. Dalam konteks kesehatan ideal, Dadang Hawari menambahkan kesehatan spiritual sebagai dimensi kesehatan yang 
ROFI'UDIN: Konsep Kebahagiaan...

holistik. Jika dijabarkan, dimensi kesehatan holistik tersebut adalah agama, organobiologik, psiko-edukatif dan sosial budaya.

1. Agama atau spiritualitas, yang merupakan fitrah manusia. Ini merupakan fitrah manusia yang menjadi kebutuhan dasar manusia (basic spiritual needs), mengandung nilai-nilai moral, etika dan hukum. Atau dengan kata lain seseorang yang taat pada hukum, berarti ia bermoral dan beretika, seseorang yang bermoral dan beretika berarti ia beragama (no religion without moral, no moral without law).

2. Organo-biologik, mengandung arti fisik (tubuh/jasmani) termasuk susunan syaraf pusat (otak), yang perkembangannya memerlukan makanan yang bergizi, bebas dari penyakit, yang kejadiannya sejak dari pembuahan, bayi dalam kandungan, kemudian lahir sebagai bayi, dan seterusnya melalui tahapan anak (balita), remaja, dewasa dan usia lanjut.

3. Psiko-edukatif, adalah pendidikan yang diberikan oleh orang tua (ayah dan ibu) termasuk pendidikan agama. Orang tua merupakan tokoh imitasi dan identifikasi anak terhadap orang tuanya. Perkembangan kepribadian anak melalui dimensi psikoedukatif ini berhenti hingga usia 18 tahun.

4. Sosial-budaya, selain dimensi psiko-edukatif di atas kepribadian seseorang juga dipengaruhi oleh kultur budaya dari lingkungan sosial yang bersangkutan dibesarkan. ${ }^{48}$

\section{E. Kebahagiaan Etis-Transendental}

Keinginan manusia untuk hidup bahagia di zaman modern ini terbentur oleh proses sekularisasi yang mencapai batasnya. Manusia modern mulai kehilangan standar moral dan menyandarkan konsep hidupnya kepada hal-hal yang bersifat pragmatis dan relatif. Standar moralnya mulai luntur oleh tekanan dan tuntutan hidup sehingga dimensi transenden dari kemanusiaan kian tergerus. Padahal, sejak era Plato dan Aristoteles hingga era modern sekarang ini, kehidupan bahagia digambarkan sebagai kehidupan yang baik secara moral, dan diatur oleh beberapa standar obyektif yang lebih besar. Sebab tanpa dimensi transenden atau standar kebaikan obyektif, kebahagiaan menjadi begitu subyektif dan relatif.49

TEOLOGIA, VOLUME 24, NOMOR 2, JULI-DESEMBER 2013 
ROFI'UDIN: Konsep Kebahagiaan...

Kebanyakan manusia modern hanya mengejar kesenangan yang pragmatis, sementara kebahagiaan yang hakiki luput dari perhatiannya. Menurut mereka, kesenangan dan kebahagiaan adalah dua hal yang tidak berbeda, padahal keduanya sebenarnya tidaklah sama. Senang dapat dirasakan oleh binatang maupun manusia, tetapi bahagia khusus dirasakan oleh manusia.

Kesenangan itu bersifat relatif, sedangkan kebahagiaan bersifat hakiki. Segala sesuatu ada yang bersifat relatif dan ada pula yang bersifat hakiki. Sesuatu disebut bersifat relatif apabila ia memiliki sifat yang dikaitkan dengan sesuatu yang lain; dan sesuatu disebut bersifat hakiki apabila ia mempunyai sifat yang terjadi tanpa didahului oleh sifat yang lain. Sesuatu yang bersifat relatif itu mungkin dinilai berbeda antara satu orang dengan yang lainnya, tetapi yang hakiki dinilai sama bagi setiap orang.

\section{Perbedaan Psikologi dan Tasawuf}

\begin{tabular}{|l|l|l|}
\hline \multicolumn{1}{|c|}{ Aspek } & \multicolumn{1}{|c|}{ Psikologi } & \multicolumn{1}{c|}{ Tasawuf } \\
\hline Ada sejak & Sekitar 100 tahun yang lalu & 1400 tahun yang lalu \\
\hline Tujuan & $\begin{array}{l}\text { Prediksi dan kontrol terhadap } \\
\text { perilaku manusia }\end{array}$ & $\begin{array}{l}\text { Pengetahuan diri, } \\
\text { pengetahuan terhadap } \\
\text { pencipta }\end{array}$ \\
\hline Metode & Kuantitatif, impersonal & Kualitatif, personal \\
\hline $\begin{array}{l}\text { Definisi } \\
\text { masalah }\end{array}$ & Sakit mental & Jiwa yang tidak sehat \\
\hline Tujuan & Kesehatan mental & $\begin{array}{l}\text { Menyembuhkan jiwa, } \\
\text { penyatuan dengan yang } \\
\text { dicintai }\end{array}$ \\
\hline $\begin{array}{l}\text { Metode } \\
\text { utama }\end{array}$ & Menekankan pada dialog & $\begin{array}{l}\text { Menekankan pada } \\
\text { pengalaman }\end{array}$ \\
\hline $\begin{array}{l}\text { Hasil } \\
\text { perubahan }\end{array}$ & Sedikit, penampilan, adaptasi & $\begin{array}{l}\text { Dalam, permanen, } \\
\text { transformasi }\end{array}$ \\
\hline Fokus & Manusia & Tuhan \\
\hline
\end{tabular}


ROFI'UDIN: Konsep Kebahagiaan...

Perbedaan Psikologi Kontemporer dan Psikologi Sufistik

\begin{tabular}{|c|c|c|}
\hline Aspek & Psikologi Kontemporer & Psikologi Sufistik \\
\hline Dimensi & Humanisme-antroposentris & Humanisme-teosentris \\
\hline Obyek Kajian & Empiris positivistik & Empiris transendental \\
\hline Ontologi & $\begin{array}{l}\text { 1. Wilayah yang teramati } \\
\text { (observable area) }\end{array}$ & $\begin{array}{l}\text { 1. Wilayah yang teramati } \\
\text { (observable area) } \\
\text { 2. Wilayah yang } \\
\text { terpikirkan (conceivable } \\
\text { area) } \\
\text { 3. Wilayah yang tak } \\
\text { terpikirkan } \\
\text { (unconceivable area) }\end{array}$ \\
\hline Epistemologi & 1. Akal (rasional-filosofis) & $\begin{array}{l}\text { 1. Akal (rasional-filosofis) } \\
\text { 2. Wahyu (ilham, intuisi, } \\
\text { kasyf; zikir, } \\
\text { kontemplasi) }\end{array}$ \\
\hline Aksiologi & Science for science & Science for value/morality \\
\hline Aliran & $\begin{array}{ll}\text { 1. } & \text { Psikoanalisa } \\
\text { 2. } & \text { Psikologi Humanistik } \\
\text { 3. } & \text { Psikologi Transpersonal } \\
\text { 4. } & \text { Psikologi Positif }\end{array}$ & $\begin{array}{ll}\text { 1. } & \text { Tasawuf falsafì } \\
\text { 2. } & \text { Tasawuf akhlāqī } \\
\text { 3. } & \text { Tasawuf 'amalì }\end{array}$ \\
\hline
\end{tabular}

\section{F. Penutup}

Berdasarkan uraian di atas, maka dapat disimpulkan bahwa kebahagiaan dalam psikologi sufistik bersifat etis-transendental. Kebahagiaan yang diraih bukan semata-mata hasil usaha manusia (maqāmāt), tetapi merupakan pemberian (Ahwwāl) dari Allah atas usaha tersebut. Mencari kebahagiaan adalah tugas dan kewajiban manusia, sedangkan hasilnya merupakan urusan Allah. Tidak ada kaitan antara usaha dan hasil, meskipun usaha merupakan salah satu cara mendapatkan hasil. Usaha manusia mencapai kebahagiaan bukan satu-satunya cara sebab ada wewenang Sang Sumber Pemberi Kebahagiaan.

Konsep kebahagiaan seperti ini sangat berbeda dari konsep yang ditawarkan dalam psikologi kontemporer yang deistik. Kebahagiaan dalam psikologi kontemporer menempatkan manusia sebagai titik sentral pemaknaan atas nilai kebahagiaan. Hal ini dapat dilihat dari

TEOLOGIA, VOLUME 24, NOMOR 2, JULI-DESEMBER 2013 
ROFI'UDIN: Konsep Kebahagiaan...

beberapa ontologi kebahagiaan yang berada pada wilayah yang teramati (observable area), seperti kekayaan, kesehatan, maupun pendidikan. Padahal faktor kebahagiaan tidak sekadar ketiga indikator tersebut. Adrian White dalam "Peta Kebahagiaan Dunia" dan beberapa penelitian lainnya menunjukkan disparitas dan paradoks tersebut. Dengan demikian, jalan-jalan kebahagiaan hendaknya disesuaikan dengan arahan dan bimbingan dari Sang Pemilik Kebahagiaan Sejati. Metode-metode sufistik, seperti mujāhadah, riyāḍah, takhallī, taḥallī, tajallī, dan sebagainya, merupakan beberapa cara yang ditawarkan dalam tujuan mencapai kebahagiaan sejati itu.]

\section{Catatan Akhir}

${ }^{1}$ Nurcholish Madjid, Islam Universal, Yogyakarta: Pustaka Pelajar, 2007, h. 269.

${ }^{2}$ Sigmund Freud, Civilization and Its Discontents, Buckinghamshire, England: Chrysoma Associates Ltd., 2005, h. 7.

3Ibid., h. 7.

${ }^{4}$ Ibid.,h. 11.

5Lihat uraiannya dalam Abraham $\mathrm{H}$. Maslow, Motivation and Personality,New York, NY: Harper \& Row, 1987, h. 15-22.

6Victor Frankl, Man's Search for Meaning, Boston, MA: Beacon Press, 1992, h. 118.

${ }^{7}$ Hanna Djumhana Bastaman, Integrasi Psikologi dengan Islam,h. 54.

${ }^{8}$ Akyas Azhari, Psikologi Umum dan Perkembangan, Jakarta: Teraju Mizan, 2004, h. 21-22.

9Brent Dean Robbins,"What is the Good Life? Positive Psychology and the Renaissance of Humanistic Psychology,"The Humanistic Psychology, 2008, h. 36, 96.

${ }^{10}$ Cziksentmihalyi mendefinisikan flow sebagai "suatu keadaan dimana orang menjadi sangat dilibatkan dalam suatu aktivitas yang tampak sangat berarti; pengalaman yang sangat menyenangkan yang orang-orang akan berlanjut melakukannya bahkan pada biaya besar, demi melakukan itu." Lihat Mihaly Csikszentmihalyi, Flow: The Psychology of Optimal Experience, New York: Harper and Row, 1990,h. 4. Pengertian flow ini 
barangkali lebih mudah dipahami sebagai suatu keterhanyutan, keterlibatan, hobi, atau penyaluran bakat dan minat.

${ }^{11}$ Ed Diener, et. al., Subjective Well-Being: the Science of Happiness and Life Satisfaction, dalamC.R. Snyder \& Shane J. Lopez eds), Handbook of Positive Psychology, New York: Oxford of University Press, 2002,h. 63.

${ }^{12} \mathrm{Abdul}$ Mudjib dan Jusuf Mudzakir, Nuansa-Nuansa Psikologi Islam,

Jakarta: Rajawali Press, 2000, h. 15.

${ }^{13}$ Abdullah Hadziq, "Psikologi Sufistik, h. 441-443.

${ }^{14} \mathrm{Abū}$ Nașr al-Sarrāj al-Țūsī, al-Luma', Abd al-Ḥalīm Maḥmūd ed.),

Mișr: Dār al-Kutub al-Hadīšah, 1960, h. 422.

${ }^{15}$ Sumadi Suryabrata, Metodologi Penelitian,Jakarta: CV. Rajawali, 1987, h. 4-5.

${ }^{16}$ Baca uraian lebih lengkap dalam Al-Ghazālī, Keajaiban-Keajaiban

Hati, terj. Muhammad Al Baqir, Bandung: Karisma, 2000, h. 96-106.

${ }^{17}$ Abdullah Hadziq, Psikologi Sufistik,h. 443.

${ }_{18}$ Alī ibn 'Uṡmān al-Jullābī al-Hujwirī, Kasyf al-Mahjūb: Risalah Persia

Tertua tentang Tasawuf,terj. Abdul Hadi WM, Bandung: Mizan, 1993, h. 345.

${ }^{19} \mathrm{QS}$. al-Syams [91]: 9-10.

${ }^{20}$ al-Hujwirī, Kasyf al-Mahjū

${ }^{21}$ Moh. Saifulloh al Aziz Senali, Risalah Memahami Ilmu Tashawwuf, Ahwāl Surabaya: Terbit Terang, 1998, 92-93 dan bandingkan Muhammad Amīn al-Kurdī, Tanwīr al-Qulūb: Jalan ke Surga, Pengembaraan Spiritual Menuju Pencerahan Qalbu, terj. M. Yaniyullah, Bandung: PT. Remaja Rosdakarya, 2005, 232-234.

${ }^{22}$ Amīn al-Kurdī, Tanwìr al-Qulūb, h. 233-234.

${ }^{23}$ QS. al-Naḥl [16]: 90.

24al-Hujwirī, Kasyf al-Mahjūb, h. 213.

25Totok Jumantoro \& Samsul Munir Amin, Kamus Ilmu Tasawuf, Jakarta: Amzah, 2005, h. 7-8.

${ }^{26}$ Seperti dikutip Media Zainul Bahri, Menembus Tirai Kesendirian-

Nya: Mengurai Maqāmāt dan Ahwāl dalam Tradisi Sufi,Jakarta: Prenada, 2005, 31.

${ }^{27} \mathrm{Al}-\mathrm{T}$ ūsī, al-Luma', h. 65.

28Ibid., h. 68-81.

29Ibid., h. 82-104.

${ }^{30} \mathrm{QS}$. al-A'rāf [7]: 143.

${ }^{31}$ Reynold A. Nicholson, Mistik dalam Islam, Terj.Tim Penerjemah

Bumi Aksara, Jakarta: Bumi Aksara, 2000, 22.

${ }^{32}$ QS. al-Kahf [18]: 17

TEOLOGIA, VOLUME 24, NOMOR 2, JULI-DESEMBER 2013 
ROFI'UDIN: Konsep Kebahagiaan... h. 230.

${ }^{33}$ M. Alfatih Suryadilaga, Miftahus Sufi Aḥwāl Yogyakarta; Teras, 2008,

${ }^{34}$ Aboe Bakar Atjeh, Pengantar Ilmu Tarekat, Ahwāl Solo: Ramadhani, 1993, h. 74.

35Mustafa Zahri, Kunci memahai Ilmu Tasawuf, Jakarta: Bina Ilmu, 1995, h. 59.

36UNDP, Human Development Report 2011, h. 130.

37UNDP, Human Development Report 2011, h. 127-130.

${ }^{38} \mathrm{~A}$ nation's level of happiness was most closely associated with health levels Ahwāl correlation of 0.62, followed by wealth Ahwāl correlation 0.52, and the provision of education Ahwāl correlation 0.51.Seperti dikutip Cynthia G. Wagner.The Well-Being of Nations.The Futurist.Ahwāl Nov-Dec 2006, h. 12.

39Ed Diener and Martin E.P. Seligman, "Beyond Money: Toward an Economy of Well-Being,"Psychological Science, 5, 2004, h.1, 3.

${ }^{40}$ www.infokito.net, posted May 21, 2008, Retrieved Nov. 19, 2011.

${ }^{41}$ Callahan, S. "Happiness Examined",America, 200Ahwāl 6, 21. Retrieved March 2, 2011, from ProQuest Religion. Document ID: 1650952571.

${ }^{42}$ Anonymous, "Morality and Happiness", Transactions of the American Philosophical Society, 98, 2008, h. 4, 59. Retrieved March 2, 2011, from ProQuest Religion. Ahwāl Document ID: 1626549561.

${ }^{43}$ University of British Columbia. Money Buys Happiness When You Spend On Others, Study Shows. ScienceDaily, 21 Mar. 2008. Web. 3 Aug. 2011.

${ }^{44}$ Diener, E. and C.Diener, "Most People are Happy,"Psychological Science, 73),1996, h. 181-184.

45Marianna Krejci-Papa,2006, March. Happier Ever After. Science \& Spirit, 17Ahwāl 2,61. Retrieved March 2, 2011, from ProQuest Religion. Document ID: 1012271651.

46Anonymous, "Family, Religion Make Youth Happy, Survey Says",Anglican Journal, 133, Oct 2007, h. 8, 8. Retrieved March 2, 2011.

${ }^{47} \mathrm{Health}$ is a state of complete physical, mental and social well-being and not merely the absence of disease or infirmity.

${ }^{48}$ Dadang Hawari, PsikiaterAl-Quran: Ilmu Kedokteran Jiwa dan Kesehatan Jiwa, Yogyakarta: PT Dana Bhakti Prima Yasa, 2004, h. 33-34.

${ }^{49}$ Callahan, S. Happiness Examined,h. 20. 


\section{DAFTAR PUSTAKA}

Anonymous, "Family, Religion Make Youth Happy, Survey Says," Anglican Journal, 133(8), Oct., 2007. Retrieved March 2, 2011.

Anonymous, "Morality and Happiness," Transactions of the American Philosophical Society, 98(4), 2007. Retrieved March 2, 2011, from ProQuest Religion.Document ID: 1626549561.

Atjeh, Aboe Bakar, Pengantar Ilmu Tarekat,Solo: Ramadhani, 1993.

Azhari, Akyas, Psikologi Umum dan Perkembangan, Jakarta: Teraju Mizan, 2004.

Bahri, Media Zainul, Menembus Tirai Kesendirian-Nya: Mengurai Maq ām āt dan Ahw āl dalam Tradisi Sufi,Jakarta: Prenada, 2005.

Bastaman, Hanna Djumhana, Integrasi Psikologi dengan Islam: Menuju Psikologi Islami, Yogyakarta: Pustaka Pelajar, 2005.

Callahan, S. "Happiness Examined,"America, 2006. Retrieved March 2, 2011, from ProQuest Religion.Document ID: 1650952571.

Csikszentmihalyi, Mihaly, Flow: The Psychology of Optimal Experience,New York: Harper and Row, 1990.

Diener, Ed and C.Diener.1996. Most People are Happy. Psychological Science, 73.

Diener, Ed and Martin E.P. Seligman. 2004. Beyond Money: Toward an Economy of Well-Being.Psychological Science,51.

Frankl, Victor, Man's Search for Meaning, Boston, MA: Beacon Press, 1992.

Freud, Sigmund, Beyond the Pleasure Principle, New York \& London: W.W. Norton \& Company, 1961.

Freud, Sigmund, Civilization and Its Discontents, Buckinghamshire, England: Chrysoma Associates Ltd., 2005.

Ghazālī, Keajaiban-Keajaiban Hati, Terj.Muhammad Al Baqir, Bandung: Karisma, 2000.

TEOLOGIA, VOLUME 24, NOMOR 2, JULI-DESEMBER 2013 
Hadziq, Abdullah, "Psikologi Sufistik: Solusi Pengembangan Pendidikan Multikultural”, Teologia, 192, Juli 2008.

Hawari, Dadang, PsikiaterAl-Quran: Ilmu Kedokteran Jiwa dan Kesehatan Jiwa, Yogyakarta: PT Dana Bhakti Prima Yasa, 2004.

Hujwirī, 'Alī ibn 'Uṡmān al-Jullābī, Kasyf al-Mahjūb: Risalah Persia Tertua tentang Tasawuf,terj.Abdul Hadi WM, Bandung: Mizan, 1993.

Ikhrom, "Titik Singgung Antara Tasawuf, Psikologi Agama, dan Kesehatan Mental", Teologia, Volume 19, No.1, Januari 2008.

Jumantoro, Totok dan Samsul Munir Amin, Kamus Ilmu Tasawuf, Jakarta: Amzah, 2005.

Kartono, Kartini, Psikologi Umum, Bandung: Mandar Maju, 1990.

Krejci-Papa, Marianna. 2006, March. Happier Ever After. Science \& Spirit, 172.Retrieved March 2, 2011, from ProQuest Religion.Document ID: 1012271651.

Kurdī, Muhammad Amīn, Tanwīr al-Qulūb: Jalan ke Surga, Pengembaraan Spiritual Menuju Pencerahan Qalbu, terj.M. Yaniyullah, Bandung: PT. Remaja Rosdakarya, 2005.

Madjid, Nurcholish, Islam Universal, Yogyakarta: Pustaka Pelajar, 2007.

Maslow, Abraham H., Motivation and Personality,New York, NY: Harper \& Row, 1987.

Mudhofir, Ali, Kamus Filsuf Barat, Yogyakarta: Pustaka, 2001.

Mudjib, Abdul dan Jusuf Mudzakir, Nuansa-Nuansa Psikologi Islam, Jakarta: Rajawali Press, 2000.

Muhadjir, Noeng, Metodologi Penelitian Kualitatif, Edisi III Yogyakarta: Rake Sarasin, 1996.

Nicholson, Reynold A., Mistik dalam Islam, Terj.Tim Penerjemah Bumi Aksara, Jakarta: Bumi Aksara, 2000.

Rajabi, Mahmoud, Horison Manusia, Terj.Yusuf Anas, Jakarta: Al Huda, 2006, 250. 
Robbins, Brent Dean. 2008. What is the Good Life? Positive Psychology and the Renaissance of Humanistic Psychology.The Humanistic Psychology, 36.

Senali, Moh. Saifulloh al Aziz, Risalah Memahami Ilmu Tashawwuf, Surabaya: Terbit Terang, 1998.

Snyder, C.R. \& Shane J. Lopez Eds., Handbook of Positive Psychology, New York: Oxford of University Press, 2002.

Suryabrata, Sumadi, Metodologi Penelitian Jakarta: CV. Rajawali, 1987.

Suryadilaga, M. Alfatih, Miftahus Sufi Yogyakarta; Teras, 2008.

UNDP, Human Development Report 2011.

University of British Columbia. Money Buys Happiness When You Spend On Others, Study Shows. ScienceDaily, 21 Mar. 2008. Web. 3 Aug. 2011.

Ṭūsī, Abū Nașr al-Sarrāj, al-Luma', Abd al-Ḥalīm Maḥmūd (ed.),Miṣr: Dār al-Kutub al-Ḥadīsiah, 1960.

Wagner, Cynthia G..The Well-Being of Nations.The Futurist.Nov-Dec 2006.

www.infokito.net, posted May 21, 2008, Retrieved Nov. 19, 2011.

Zahri, Mustafa, Kunci memahai Ilmu Tasawuf, Jakarta: Bina Ilmu, 1995. 